\title{
Estimating the potential distribution and conservation priorities of Chironectes minimus (Zimmermann, 1780) (Didelphimorphia: Didelphidae)
}

\author{
David A. Prieto-Torres ${ }^{1,2,3^{*}}$ and Gonzalo Pinilla-Buitrago ${ }^{2,4,5}$
}

${ }^{1}$ Eje BioCiencias, Centro de Modelado Científico de la Universidad del Zulia (CMC-LUZ), Facultad Experimental de Ciencias. Calle 65 con Av. Universidad, sector Grado de Oro, Estado Zulia, Maracaibo 4004, Venezuela. E-mail: dprieto@cmc.org.ve (DAPT)

${ }^{2}$ Red de Biología Evolutiva, Laboratorio de Bioclimatología, Instituto de Ecología, A.C. Carretera antigua a Coatepec 351, CP. 91070, Xalapa. Veracruz, México. E-mail: gepinillab@gmail.com (GEPB)

${ }^{3}$ Museo de Biología de la Universidad del Zulia (MBLUZ), Facultad Experimental de Ciencias. Calle 65 con Av. Universidad, sector Grado de Oro, Estado Zulia, Maracaibo 4004, Venezuela.

${ }^{4}$ Grupo de Mastozoología Universidad Nacional de Colombia, Facultad de Ciencias, Universidad Nacional de Colombia. Calle 26, Bogotá 111321. Distrito Capital, Colombia.

${ }^{5}$ Grupo en Conservación y Manejo de Vida Silvestre, Instituto de Ciencias Naturales, Facultad de Ciencias, Universidad Nacional de Colombia Calle 26, Bogotá 111321. Distrito Capital, Colombia.

${ }^{*}$ Corresponding author

The water opossum (Chironectes minimus) is an elusive and solitary Neotropical semi-aquatic species, whose population dynamics cannot be studied using traditional methods to capture small mammals. Therefore, some aspects of its distribution, habitat requirements, and abundance are mostly unknown; which makes a proper determination of its conservation status difficult. Considering that new techniques known as species distribution models (SDMs) allow us to estimate the suitable areas and the most important variables for the distribution of a species, we compiled water opossum occurrences and modeled its potential distribution on a continental scale. We performed a SDM for the water opossum using MaxEnt and assessed the extent of habitat loss $\left(\mathrm{km}^{2}\right)$ and the importance of Protected Areas (PAs). We compared the suitability values within and outside PAs using a Kolmogorov-Smirnov (KS) test to evaluate the efficiency of PAs. The results obtained were compared with the IUCN historical water opossum's map. Additionally, we identified gaps in the potential distribution where for future surveys should be focused. We obtained models that describe the distribution of this species based on 292 occurrences with new information for 16 countries. Deforestation reduced the area of suitable habitat by $\sim 40 \%$ and only $\sim 18 \%$ corresponds to natural forest within PAs. Areas inside PAs showed higher suitability values $(0.351 \pm 0.276 ; P<0.001)$ than areas outside them. We identified gaps within the distribution that need attention during future surveys such as the frontier between Venezuela and Guyana, the Amazonian region, and central-eastern Brazil. Our results showed areas absent in the IUCN's distribution map, indicating that it needs to be updated. Thus, we proposed a new tentative extent of the water opossum distribution information here obtained. We demonstrated that PAs included areas with high habitat suitability values for $C$. minimus, which could protect the water opossum in the medium and long-term. Modifications to the physicochemical characteristics of the habitat due to forest loss and fragmentation can considerably affect water opossum populations and reduce local diversity. Thus, the preservation of river ecosystems and surrounding areas represents a necessary step for the conservation of C. minimus.

La zarigüeya de agua (Chironectes minimus) es una especie neotropical semi-acuática, de hábitos esquivos y solitarios, cuya dinámica poblacional no puede ser estudiada métodos tradicionales de captura de pequeños mamíferos. Es por ello que algunos aspectos de su distribución, sus requerimientos de hábitat y su abundancia siguen siendo desconocidos, dificultando su apropiada categorización. Considerando que modelos de distribución de especies (MDE) nos permiten estimar y las variables climáticas más importantes para la distribución; se recopilaron las ocurrencias de C. minimus y se modelo su distribución potencial a una escala continental. Utilizando el programa MaxEnt se definió un MDE para la zarigüeya de agua, evaluando el efecto de la pérdida de hábitat $\left(\mathrm{km}^{2}\right.$ ) y la importancia de las Áreas Protegidas (AP) en la extensión del mismo. La eficiencia de las APs fue evaluada con una prueba de Kolmogorov-Smirnov (KS) para comparar los valores de idoneidad del MDE obtenidos dentro y fuera de las APs. Los resultados obtenidos se compararon con el mapa de distribución histórica de la UICN. Adicionalmente, se identificaron vacíos de información en la distribución potencial donde enfocar esfuerzos de muestreo mediante el cálculo de un índice de prioridad. Se obtuvieron modelos a partir de 292 ocurrencias, con nueva información en 16 países. La deforestación redujo la distribución potencial en $\sim 40 \%$ y se observó que solo el 18\% corresponde a bosques naturales dentro de las AP. Las áreas de distribución potencial mostraron valores de idoneidad más altos dentro de las APs $(0,351 \pm 0,276, p<0,001)$. Las áreas con vacíos de información fueron identificadas en la frontera entre Venezuela y Guyana, la región amazónica y el centro-este de Brasil. Los resultados indican áreas de distribución ausentes en el mapa de la UICN, sugiriendo que este necesita ser actualizado. Por lo tanto, se propone una nueva distribución de la zarigüeya de agua. Se demostró que las APs incluyeron áreas con altos valores de idoneidad de hábitat para C. minimus; lo que podría favorecer su protección a medio y largo plazo. Las modificaciones de las características fisicoquímicas del hábitat por la pérdida y fragmentación de los bosques pueden afectar considerablemente a las poblaciones de zarigüeyas de agua y reducir la diversidad local. La preservación de los ecosistemas fluviales y las áreas circundantes en su conjunto representa un paso esencial para la conservación de $C$. minimus.

Key words: conservation; ecological niche models; mammals; marsupials; species distribution models; water opossum.

C 2017 Asociación Mexicana de Mastozoología, www.mastozoologiamexicana.org 


\section{Introduction}

The water opossum or Yapok, Chironectes minimus (Zimmerman 1780), is the only Neotropical semi-aquatic marsupial (Bressiani and Graipel 2008; Acosta and Azurduy 2009; Galliez et al. 2009). It belongs to a monotypic genus, which includes four subspecies (Stein and Patton 2007; Damasceno and Astúa 2016). The species is characterized by a silvery gray dorsal pelage with four black transverse patches connected by a narrow midline. Water opossums are adapted to semi-aquatic habitats, with several external morphological adaptations: 1) dense, short, and waterresistant pelage, 2) webbed hindfeet to swim, 3) impermeable pouch in females to keep the young dry, and 4) the ability to protect the male genitalia in the water with an incomplete pouch (Mondolfi and Medina 1957; Marshall 1978; Stein and Patton 2007; Voss and Jansa 2009).

Water opossums are widely distributed in the Neotropics (Figure 1), from southern Mexico to northeastern Argentina (Nowak 1999; Cuarón et al. 2008). This elusive and solitary species is mainly associated with river channels with stony substrates, clear and fast-running waters, and preserved riparian vegetation (Prieto-Torres et al. 2008; Galliez et al. 2009; Galliez and Fernandez 2012; Ardente et al. 2013). However, it is a species whose large-scale population dynamics (e. g., distribution and abundance) cannot be studied using traditional methods, because they are not usually captured in common live traps for small mammals (Bressiani and Graipel 2008; Prieto-Torres et al. 2011). In fact, although there are some studies on the behavior, demographic patterns, habitat selection, morpho-physiological and genetic analyses of water opossums (e. g., Nogueira et al. 2004; Galliez et al. 2009; Palmeirim et al. 2014; Fernandez et al. 2015), most of them are not-specific, faunistic surveys (e. g., Handley 1976; Oliveira et al. 2007; Prieto-Torres et al. 2008; 2011; Ardente et al. 2013).

The water opossum is listed as Least Concern (Cuarón et al. 2008) on the International Union for Conservation of Nature (IUCN) red list due to its wide distribution, presumably large population, and its presence in several protected areas or "PAs" (Oliveira et al. 2007; Galliez et al. 2009; Ardente et al. 2013). However, recent work suggests a decreasing population trend in Brazil, where the species is considered threatened in at least five states due to habitat loss and degradation (Ardente et al. 2013; Palmeirim et al. 2014; Fernandez et al. 2015). Thus, there is an increasing need to define its actual distribution and ecological requirements (Cuarón et al. 2008).

The minimum convex polygon method is frequently used to estimate species' distribution (IUCN 2001, 2015), but ignores the species' ecological constraints (Brown et al. 1996; Mota-Vargas and Rojas-Soto 2012; Peterson et al. 2016). Thus, techniques like species distribution models (SDMs) have been developed to predict the potential dis- tribution of a species, identifying the suitable areas and the most important variables for the persistence of the species (Peterson 2001; Soberón and Peterson 2005; Stohlgren et al. 2011). These models are widely used in ecology, evolution, conservation, and management (e. g., Soberón and Peterson 2005; Stohlgren et al. 2011; Tôrres et al. 2012; OrtegaAndrade et al. 2013; 2015).

Due to the lack of information on the distribution of $C$. minimus, in this study we modeled its potential distribution on a continental scale, following part of the methodology of Rheingantz et al. (2014) employed for another semi-aquatic mammal. We determined the effect of habitat loss in the extents of habitat suitability for species and evaluated if the current PAs systems actually harbor the most suitable environmental conditions for its distribution. Finally, we identified gaps in the potential distribution where future survey efforts and ecological studies should be focused.

\section{Material and Methods}

Collection of historical records. We compiled a database of occurrences from three sources: 1) occurrences available in on-line databases (i. e., Global Biodiversity Information Facility database [GBIF] and Mammal Networked Information System [MaNIS]); 2) specimens verified from biological collections (see Appendix 1); and 3) location records obtained from fieldwork and published literature (e. g., Handley 1976; Mares et al. 1986; Oliveira et al. 2007; Bressiani and Graipel 2008; Prieto-Torres et al. 2008; 2011; Acosta and Azurduy 2009; Ardente et al. 2013; Brandão et al. 2014; Damasceno and Astúa 2016). We verified each locality using Google Earth and MapLink (www.maplink.com), correcting imprecise coordinates and/or eliminating duplicates when necessary. Geographic coordinates were provided in decimal degrees, based on the WGS 84 datum. We obtained data from sixteen countries between 1925 and 2015 describing the historical presence of the species (Figure 1, Appendix 1). In addition, we considered the largest water opossum home range ( $\sim 3 \mathrm{~km}^{2}$; Galliez et al. 2009) as a buffer area between records and cleared the points located close together, thereby reducing sampling bias (e. g., OrtegaAndrade et al. 2015). We performed the SDM (see below) using 165 unique localities records (Appendix 1).

Species Distribution Model and validation. We modeled the potential water opossum distribution with MaxEnt version 3.3.3k (Peterson 2001; Elith et al. 2006; Phillips et al. 2006), which uses the principle of maximum entropy to calculate the most likely distribution of the focal species in function of occurrence localities and environmental variables. We used the 19 climatic variables of WorldClim 1.4 (Hijmans et al. 2005) and three topographic variables (i. e., Digital Elevation Model [DEM], Slope and Aspect) from the Hydro $1 \mathrm{~K}$ project (USGS 2001); with 30 " of resolution $\left(\sim 1 \mathrm{~km}^{2}\right.$ cell size). Despite that topographic variables are not commonly used in SDM studies, they were included because numerous examples (e. g., Mota-Vargas et al. 2013; Cauwer et al. 2014; Rheingantz et al. 2014; Kübler et al. 2016) show 


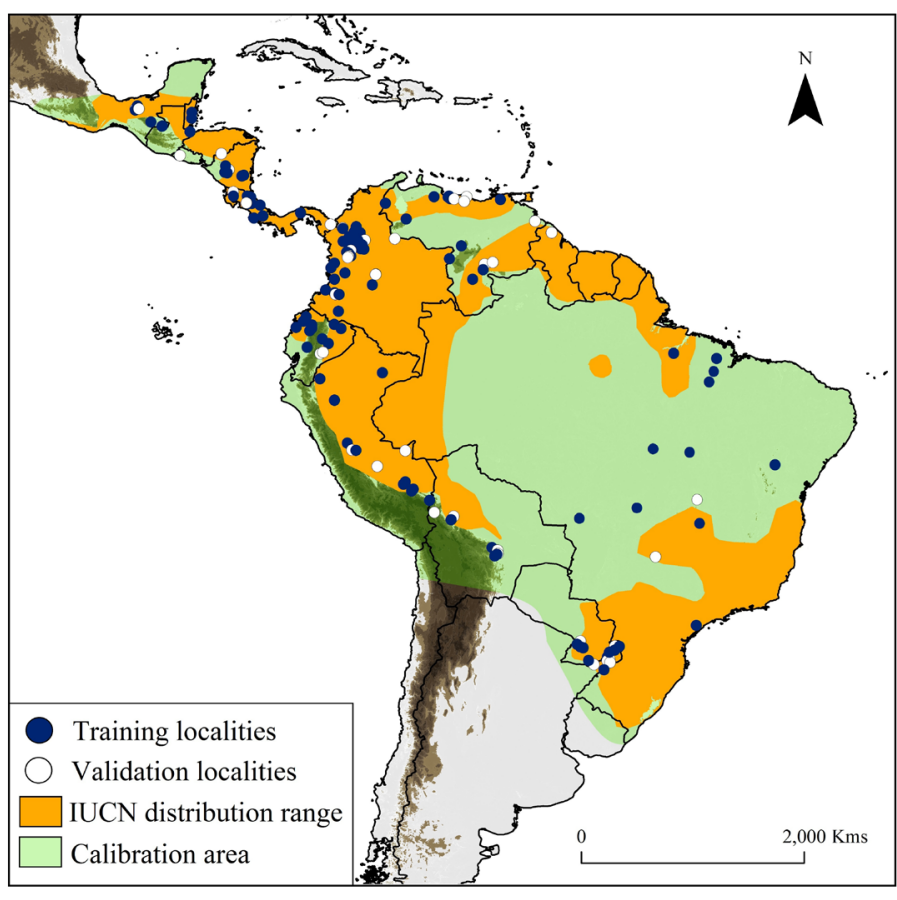

Figure 1. Map showing water opossum (Chironectes minimus) unique records $(n=165)$, overlaid with the IUCN distribution and model calibration area (light and dark green colors). Training localities (blue dots) and validation localities (white dots) were used to generate and validate the models. Dark brown color represents area with altitudes of up 1,200 m.

that these variables can be used as proxies for variables ( $e$. g., micro-climate or edaphic conditions) that are correlated with physiological requirements of species.

The potential distribution model was generated using the $75 \%(n=124)$ of the locality records and $25 \%(n=41)$ for internal evaluation. In this sense, the algorithm used localities of species records and environmental conditions to perform a certain number of iterations $(1,000$ in this case) before reaching a convergence limit. This algorithm for the logistic output produces a map of habitat suitability ranging from 0 (unsuitable) to 1 (perfectly adequate; Phillips et al. 2006; Phillips and Dubik 2008). We ran ten crossvalidate replicates to calculate confidence intervals, and the best model was selected based on the performance of area under the curve or "AUC" (Elith et al. 2006; 2011). Then, we converted the obtained logistic values of suitability rating into a binary presence-absence map, based on two established threshold values: the "Fixed cumulative value 10 " (FCV10) and the "5 percentile training presence" (5PTP; see Pearson et al. 2006; Liu et al. 2013).

It is important to note that there is no rule to set these thresholds because its selection depends on the data used or the objective of the map, and will vary from species to species. In our case, we used the FCV10 as we wanted a threshold that minimizes the commission errors in our final binary maps (Liu et al. 2013), and we used the 5PTP to identify pixels with the highest suitability values, rejecting the lowest (5\%) suitability values of training records. The 5PTP model is a sub-conjunct in the geographic and ecological space of FCV10 model.

Given that ENMs do not address the historical aspects relating to species distribution (e. g., accessibility or " $\mathrm{M}$ " sensu BAM diagram [Soberón and Peterson 2005]), we used a geographical clip (Figure 1; Appendix 2) based on the intersection of Terrestrial Ecoregions (Olson et al. 2001) and the Biogeographical Provinces of the Neotropic (Morrone 2014) to create an area for model calibration (see Anderson and Raza 2010; Barve et al. 2011; Rodda et al. 2011). We selected the uncorrelated $(r<0.8)$ and most relevant variables using the Jackknife test of MaxEnt (Royle et al. 2012). These steps allowed us to reduce over-fitting of the generated suitability models (Peterson et al. 2011). Finally, we evaluated the performance of the selected MaxEnt model with the Partial-ROC (Receiver Operating Characteristic) curves test (Lobo et al. 2008). This criterion was used to solve problems associated with an inappropriate weighting of the omission and commission errors during the AUC analysis (see Lobo et al. 2008; Peterson et al. 2008).

Spatial analysis of the water opossum' distribution in the Neotropics. We performed three distinct spatial analyses to assess the conservation issues related to the species' potential distribution: 1) to evaluate the extent of habitat loss on the model; 2) to determine if the PAs system contains the highly suitable areas for the species; and 3 ) to identify the gaps where future survey efforts should be focused. The spatial analyses and map algebra were carried out with ArcMap 10.2.2 software (ESRI 2011), with a grid cell resolution of 30 ", corresponding to $\sim 1 \mathrm{~km}^{2}$ in each raster.

First, we used a vegetation land cover map (Hansen et al. 2013) considering only two categories "natural forest" and "perturbed areas," to determine the effect of habitat loss in the obtained models. Perturbed areas included urban areas, deforested areas, farm lands, and pastures for cattle ranching (Hansen et al. 2013). The PAs extents were downloaded from ProtectedPlanet.net (IUCN and UNEP-WCMC 2012). To assess if the current PA system harbors the most suitable environmental conditions for the species we performed a Kolmogorov-Smirnov (KS) test in R (R-Core-Team 2012) comparing the suitability values within and outside PAs (Rheingantz et al. 2014). The results obtained from the deforestation and PAs analysis were compared with the IUCN species distribution.

Finally, to identify gaps in the potential distribution where future survey efforts and conservation initiatives should be focused, we followed the proposal by Rheingantz et al. (2014). In the analysis, we multiplied the suitability value of a pixel by its distance to the nearest occurrence and river, based on the assumption that ecological similarities decrease with distance among these factors. Then, we divided the index by its highest value to obtain a scale from 0 to 1 . We therefore assumed that areas with high suitability values, located far from previous studies and near to rivers (the focal species is associated with water) were more likely to be in different ecosystems or to have dissimilar environmental characteristics (Rheingantz et al. 2014). Thus, studying water opossum in those areas could explain whether the species uses different habitats than previously reported. 


\section{Results}

Historical records and SDM for water opossum. Our study includes new information on the distribution of water opossum, including a total of 292 occurrences in the 16 countries that encompass the recognized distribution ranges according to the IUCN (Figure 1; Marshall 1978; Cuarón et al. 2008). Including also new potential areas of distribution in Mexico, El Salvador, Nicaragua, Costa Rica, Colombia, Venezuela, Brazil, Bolivia, Peru and Ecuador.

The variables used and their percentage contribution to the model are shown in the Table 1 and are consistent with results found by previous studies on Neotropical mammals (e. g., DeMatteo and Loiselle 2008; Tôrres et al. 2012; Rheingantz et al. 2014). We generated a model for water opossum distribution with a high Roc-Partial result (1.23 \pm 0.09 ; $P<0.05)$. For the threshold FCV10 (0.160) and 5PTP (0.190), based on 41 test occurrences, we obtained $7 \%(n=3)$ and $5 \%(n=2)$ rates of omission, respectively. Performance assessment showed that models were statistically acceptable to describe the ecological niche and distribution of this species.

The water opossum potential distribution according to the FCV10 threshold totaled $\sim 9,238,000 \mathrm{~km}^{2}$, representing $45.9 \%$ of the total areas used in the calibration of the model (Figure 2a). This FCV10 model is $23 \%$ wider than IUCN's historical distribution map (with $\sim 72.29 \%$ overlap). Considering the 5PTP threshold, we obtained $\sim 7,787,700 \mathrm{~km}^{2}$ of potential distribution for the species, representing 38.3 $\%$ of calibration areas and is $\sim 4 \%$ greater than the IUCN's distribution map (with $\sim 65 \%$ overlap). The 5PTP's potential species distribution was smaller in almost all countries compared to the IUCN map (Figure 2a). Comparing the IUCN map and FCV10 threshold, the only regions absent in the latter were predominantly areas in Mexico, savanna in Colombia and Venezuela, amazon in Peru, and the southeast of Brazil.
Table 1. Summary of the selected environmental variables with relative contributions (\%) to the model of Chironectes minimus using MaxEnt 3.3.3k

\begin{tabular}{llc}
\hline Abbreviation & Environmental Variable & $\begin{array}{c}\text { Percentage } \\
\text { contribution }\end{array}$ \\
\hline Bio 18 & Precipitation of Warmest Quarter & 24.7 \\
Bio 11 & Mean Temperature of Coldest Quarter & 17.2 \\
DEM & Digital Elevation Model & 16.5 \\
Bio 07 & Temperature Annual Range (BIO5-BIO6) & 13.1 \\
Bio 14 & Precipitation of Driest Month & 12.9 \\
Bio 04 & Temperature Seasonality (standard deviation *100) & 7.8 \\
Bio 15 & Precipitation Seasonality (Coefficient of Variation) & 5.4 \\
Bio 01 & Annual Mean Temperature & 1.4 \\
Bio 03 & Isothermality (BIO2/BIO7) (* 100) & 0.9 \\
\hline
\end{tabular}

Deforestation impact, protected areas and future areas of study. The predicted and remnant areas of the potential distribution model for the water opossum according the threshold values are detailed in Tables 2 and 3. Deforestation reduced the area of suitable water opossum habitat by $\sim 40 \%$ (38.07 - $43.39 \%$ ). Loss in area was most pronounced in the Mesoamerican region (from Mexico to Panama), the lowlands of the Andes region (from Peru to Colombia and northwest Venezuela), and the southeast region of South America (Paraguay, Argentina and Brazil; Figure $2 \mathrm{~b}$ ). Furthermore, only 18 \% of the potential water opossum distribution corresponds to natural forest within PAs (Figure 2b-c; Tables 2-3).

The current PAs system in the Neotropics represents $\sim 20$ $\%$ of species' potential distribution (Figure 2c). Areas inside PAs showed significantly higher suitability values $(0.351 \pm$ $0.276 ; \mathrm{KS}, P<0.001)$ than areas outside them $(0.319 \pm 0.238)$. The highest values were obtained in the Amazon areas (including Bolivia, Peru, Ecuador, Colombia, Venezuela, and Brazil; Figure 2), followed by the Guiana shield and the coast of the Atlantic forest. The index of suitable value multiplied by its distance to nearest occurrence and river identified gaps (index > 0.5) within the distribution that need attention during future surveys, such as the frontier between Venezuela and Guyana (mainly in the Guiana Highlands),

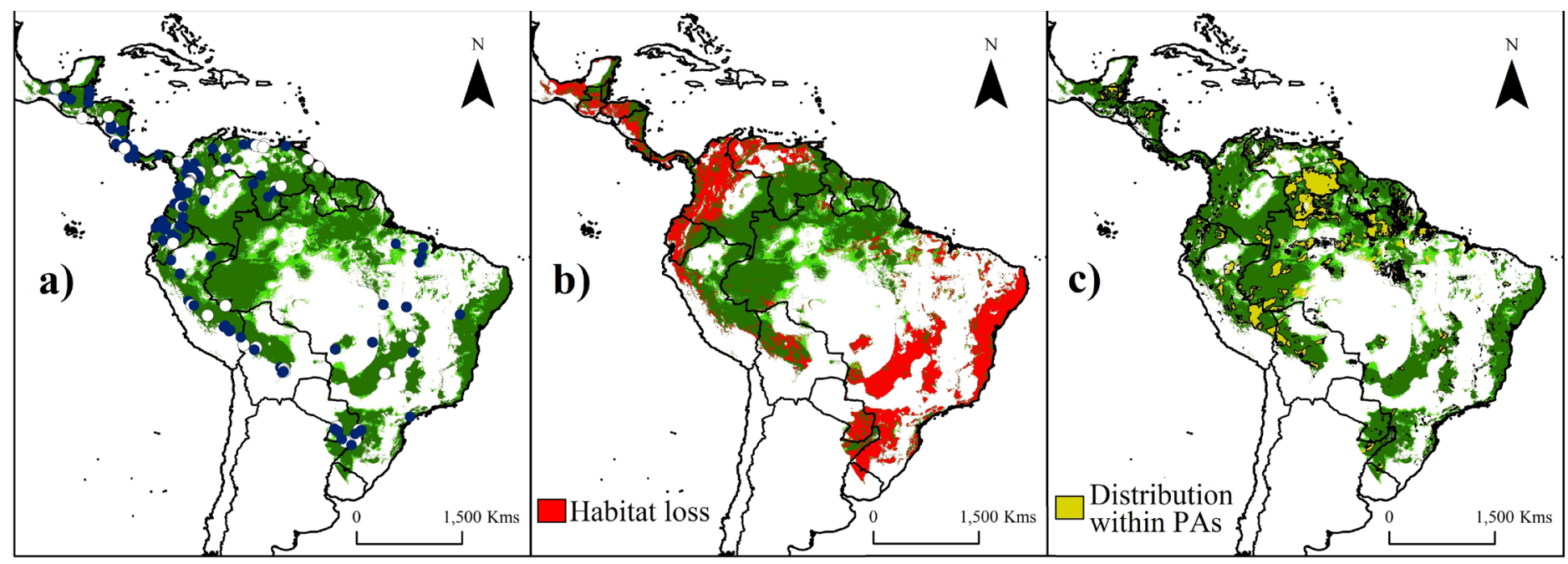

Figure 2. Potential suitability areas (a), remnant of natural forests (b) and predicted Protected Areas (c) throughout the distribution range of water opossum (Chironectes minimus). Training localities (blue dots) and validation localities (white dots) used to generate models are shown in (a). Potential distribution model (in a-c) is shown with the threshold value of Fixed cumulative value 10 (FCV10, light green) and 5 Percentile training presence (5PTP; dark green). Note an important reduction ( 40 \%, in greens [natural forests areas]) in the potential distribution model through the Mesoamerican region (from Mexico to Panama), the lowlands of the Andes region (from Peru to Colombia and northwest Venezuela), and the southeast of South America (Paraguay, Argentina and Brazil). The perturbed areas were calculated according the deforestation index map proposed by Hansen et al. (2013). Dark brown color represents area with altitudes of up $1,200 \mathrm{~m}$. 
the Amazonian region (including Colombia and the northwestern Brazil), and central-eastern Brazil (Figure 3a).

\section{Discussion}

Potential distribution range of water opossum and habitat loss effects. Our results confirm that the climate variables used in this study (Table 1) can be employed to model the potential distribution of terrestrial species associated with aquatic environments, as previously demonstrated for the otters Lontra longicaudis and Pteronura brasiliensis (Cianfrani et al. 2011; Rheingantz et al. 2014). Mean precipitation of the driest quarter and the warmest quarter were the most important variables for the water opossum's distribution in the Neotropics (Table 1), as was found for the Neotropical otter (Rheingantz et al. 2014). Altitude was another important variable which represents a gradient correlating directly with factors such as micro-climate or edaphic conditions (Mota-Vargas et al. 2013; Kübler et al. 2016). Although water opossum occurred between zero to $\sim 3,000 \mathrm{~m}$ (including the Andes region), most of the occurrences were between zero to $500 \mathrm{~m}(n=81)$ and zero to $2,000 \mathrm{~m}(n=157$; Appendix 1). This spatial distribution of species' occurrences suggests that the species has an altitudinal limit (due to climatic gradients by elevation) possibly associated with their physiological requirements. This last idea agrees with studies for the Neotropical otter, which is described as abundant at medium elevations (Lariviére 1999; Rheingantz et al. 2014).

It is important to observe that suitability model predicted for $C$. minimus was severely reduced due to habitat loss ( 36 to $43 \%$ ); even inside of PAs (Tables 2 and 3). The habitat loss is associated with areas highly threatened
Table 2. Potential distribution models for Chironectes minimus, with percentage loss of potential distribution areas by effect of habitat loss and the percentage of potential distribution within Protected Areas (PAs) in the Neotropics

\begin{tabular}{lrr}
\hline Model & Area $\left(\sim \mathbf{k m}^{\mathbf{2}}\right)$ & \multicolumn{1}{c}{$\%$} \\
\hline Extent of occurrence (minimum convex polygon) & $\mathbf{1 3 , 8 7 8 , 6 8 5}$ & - \\
IUCN distribution map & $\mathbf{7 , 5 0 1 , 1 2 4}$ & $\mathbf{1 0 0 . 0 0}$ \\
Area of the model within natural forests & $4,246,209$ & 56.61 \\
Area of the model within PAs & $1,126,857$ & 15.02 \\
Remnant model within PAs and natural forests & 978,935 & 13.05 \\
Species Distribution Model (FCV10) & $\mathbf{9 , 2 3 8 , 0 7 2}$ & $\mathbf{1 0 0 . 0 0}$ \\
Area of the model within natural forests & $5,721,975$ & 61.93 \\
Area of the model within PAs & $1,840,152$ & 19.91 \\
Remnant model within PAs and natural forests & $1,644,964$ & 17.81 \\
Species Distribution Model (5PTP) & $\mathbf{7 , 7 8 7 , 7 5 9}$ & $\mathbf{1 0 0 . 0 0}$ \\
Area of the model within natural forests & $4,726,649$ & 60.69 \\
Area of the model within PAs & $1,547,148$ & 19.87 \\
Remnant model within PAs and natural forests & $1,381,237$ & 17.74 \\
\hline
\end{tabular}

by human activities (e. g., expansion of cattle ranching and urban settlements), which remove vegetation cover thereby reducing water opossum's habitat (Prieto-Torres et al. 2008; 2011; Galliez et al. 2009). Similarly, previous studies report that the expansion of the agricultural frontier is a critical factor affecting biodiversity in the Neotropics (Shukla et al. 1990; Lees and Peres 2006; Bressiani and Graipel 2008; Ribeiro et al. 2009; Ortega-Andrade et al. 2015; Prieto-Torres et al. 2016). These conditions push the species to the edge of its distribution and increase fragmentation of predicted suitable areas, which could promote decreasing trends in populations (Ardente et al. 2013; Palmeirim et al. 2014; Fernandez et al. 2015). Thus, future conservation efforts should concentrate on reducing habitat loss and restoring identified natural habitats, especially considering

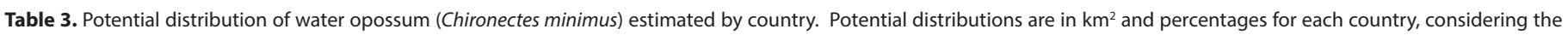
deforestation effects and PAs, based in the two threshold values used in this study.

\begin{tabular}{|c|c|c|c|c|c|c|}
\hline \multirow{2}{*}{ Country } & \multicolumn{3}{|l|}{ FCV10 } & \multicolumn{3}{|l|}{ 5PTP } \\
\hline & Modeled Area (\%) & Intact Areas (\%) & Intact areas in PAs (\%) & Modeled Area (\%) & Intact Areas (\%) & Intact areas in PAs (\%) \\
\hline Brazil & $4,555,022(49.31)$ & $2,642,873(28.61)$ & $774,870(8.39)$ & $3,604,227(46.28)$ & $1,980,563(25.43)$ & $569,951(7.32)$ \\
\hline Colombia & $1,042,751(11.28)$ & $569,586(6.16)$ & $58,024(0.63)$ & $953,324(12.24)$ & $523,079(6.72)$ & $56,206(0.72)$ \\
\hline Venezuela & 831,292 (8.99) & $590,105(6.38)$ & $383,794(4.15)$ & $741,999(9.53)$ & $549,763(7.06)$ & $366,851(4.71)$ \\
\hline Peru & 744,347 (8.06) & $653,448(7.07)$ & $136,241(1.47)$ & $651,262(8.36)$ & $567,470(7.28)$ & $124,656(1.60)$ \\
\hline Bolivia & $383,783(4.15)$ & $270,766(2.93)$ & $77,297(0.84)$ & $321,390(4.12)$ & $220,288(2.83)$ & $66,861(0.86)$ \\
\hline Ecuador & $248,756(2.69)$ & $117,683(1.27)$ & $31,479(0.34)$ & $239,138(3.07)$ & $113,795(1.46)$ & $30,714(0.39)$ \\
\hline Guyana & $211,967(2.29)$ & $201,563(2.18)$ & $19,638(0.21)$ & $172,955(2.22)$ & $163,320(2.09)$ & $17,797(0.23)$ \\
\hline Mexico & $206,711(2.24)$ & $91,310(0.98)$ & $20,817(0.22)$ & $183,380(2.35)$ & $83,238(1.06)$ & $17,907(0.23)$ \\
\hline Suriname & $155,010(1.68)$ & $150,754(1.63)$ & $16,497(0.18)$ & $126,002(1.62)$ & $122,293(1.57)$ & $10,965(0.14)$ \\
\hline Paraguay & 154,595 (1.67) & $41,180(0.44)$ & $2,809(0.03)$ & $140,937(1.81)$ & $36,895(0.47)$ & $2,803(0.04)$ \\
\hline Nicaragua & $114,767(1.24)$ & $64,038(0.69)$ & $12,556(0.14)$ & $112,145(1.44)$ & $63,173(0.81)$ & $12,546(0.16)$ \\
\hline Honduras & $112,529(1.22)$ & $44,931(0.48)$ & $6,798(0.07)$ & $108,749(1.39)$ & $44,418(0.57)$ & $6,650(0.08)$ \\
\hline Guatemala & 108,169 (1.17) & $53,141(0.57)$ & $22,504(0.24)$ & $103,319(1.33)$ & $50,843(0.65)$ & $21,417(0.27)$ \\
\hline Argentina & $102,436(1.11)$ & $65,902(0.71)$ & $17,084(0.18)$ & $90,662(1.16)$ & $58,660(0.75)$ & $16,630(0.21)$ \\
\hline French Guiana & $79,829(0.86)$ & $79,018(0.85)$ & $38,863(0.42)$ & $67,426(0.86)$ & $66,917(0.86)$ & $33,904(0.43)$ \\
\hline Panama & 73,839 (0.79) & $38,500(0.41)$ & $8,544(0.09)$ & $67,499(0.87)$ & $36,004(0.46)$ & $8,284(0.11)$ \\
\hline Costa Rica & $49,732(0.54)$ & $23,037(0.25)$ & $8,452(0.09)$ & $47,761(0.61)$ & $22,519(0.29)$ & $8,398(0.11)$ \\
\hline Uruguay & $30,447(0.33)$ & $1,642(0.017)$ & $207(0.002)$ & $24,400(0.31)$ & $1,063(0.013)$ & $207(0.002)$ \\
\hline Belize & $24,201(0.26)$ & $19,666(0.21)$ & $8,248(0.09)$ & $24,200(0.31)$ & $19,666(0.25)$ & $8,248(0.11)$ \\
\hline Trinidad and Tobago & $4,909(0.05)$ & $2,402(0.02)$ & $228(0.002)$ & $4,785(0.06)$ & 2,385 (0.03) & $228(0.003)$ \\
\hline El Salvador & $2,980(0.03)$ & $430(0.004)$ & $14(0.0001)$ & $2,199(0.03)$ & $297(0.003)$ & $14(0.0002)$ \\
\hline Total & $9,238,072(100)$ & $5,721,975(61.93)$ & $1,644,964(17.81)$ & $7,787,759$ (100) & $4,726,649(60.69)$ & $1,381,237(17.74)$ \\
\hline
\end{tabular}




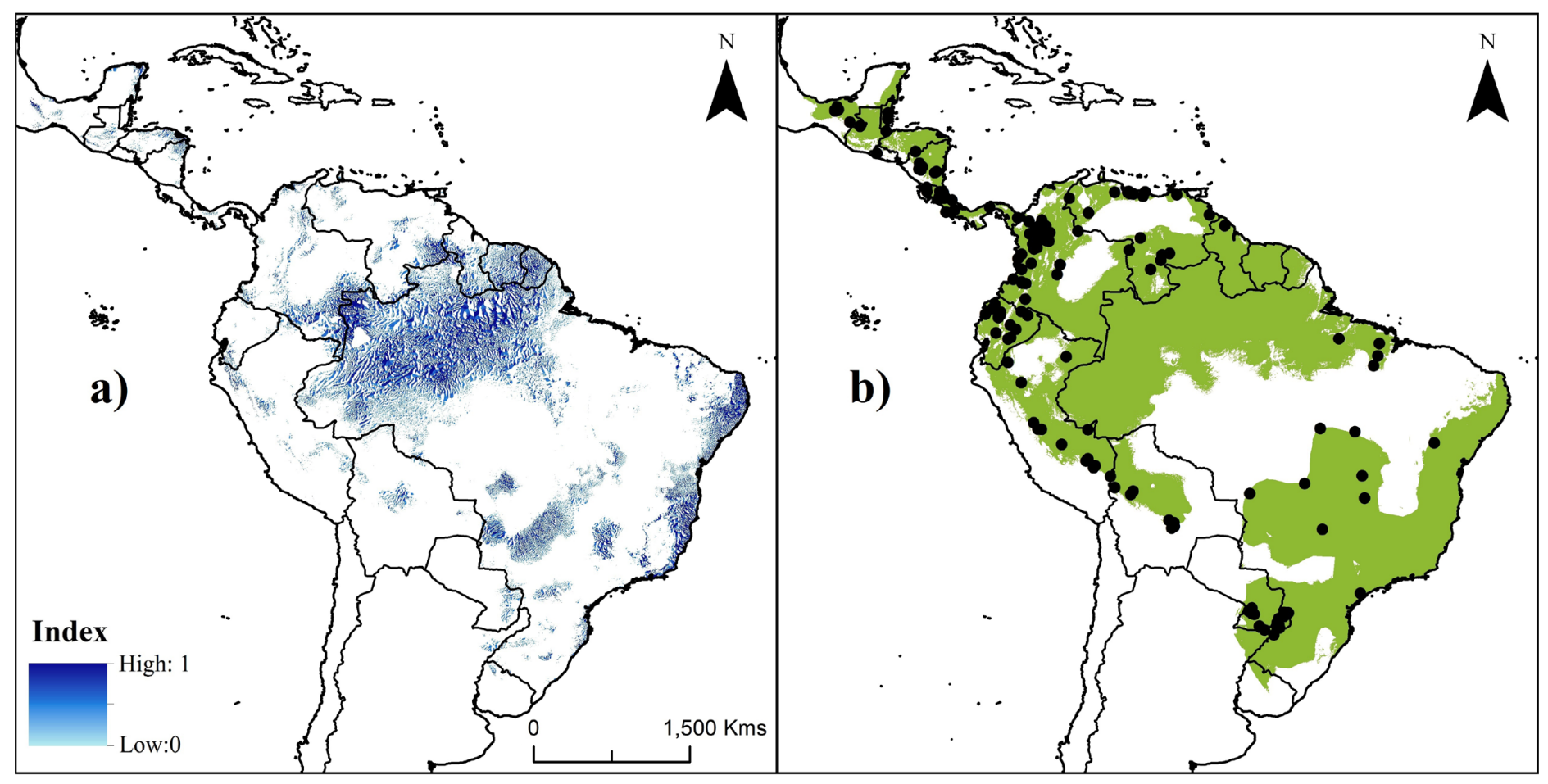

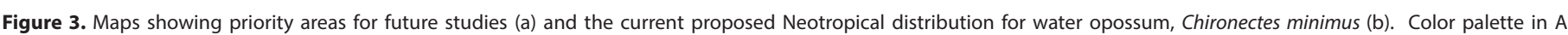

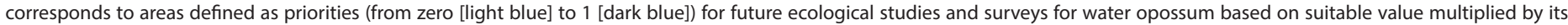
distance to nearest occurrence and water source (i. e., rivers). Black points in B represent the unique historical records $(n=165)$ of species.

the restricted home range and unknown population size of the water opossum (Galliez et al. 2009; IUCN 2015).

Protected areas and gaps in areas for future studies. We demonstrated that PAs included areas with high habitat suitability values for C. minimus, which could protect it in the medium and long-term. Furthermore, our analysis supports the idea that SDMs can be used to evaluate whether PAs are really conserving species within them. Such studies allow us to identify potential areas of conservation priority for the species to achieve more realistic conservation goals in their present and future distributions (e. g., Hannah et al. 2005, 2007; Dudley and Parish 2006; Lessmann et al. 2014).

The PAs system is especially important for the water opossum in the Amazon region, due to the low rate of deforestation of the remaining forest (Numata and Cochrane 2012). The persistence of PAs in this region will play a role in preventing environmental degradation in the central and south portion of the $C$. minimus. Meanwhile, populations along the Mesoamerican region (from Mexico to Panama), the western Andes (Ecuador, Colombia and Venezuela), and southeastern Brazil are more vulnerable to the effects of forest loss due to fewer PAs (Figure 2b-c). However, it is important to conserve not only PAs but also surrounding areas through forest restoration and sustainable development programs which include local people (Laurance et al. 2012; Rheingantz et al. 2014; Prieto-Torres et al. 2016). Additionally, studies under future climate change scenarios are needed to consider the role of the PAs system in protecting the species' habitat (e. g., Hannah et al. 2005, 2007).

We suggest that future studies (e. g., inventories, popu- lation monitoring, abundance patterns, and habitat evaluations) need to be focused on the Guiana Highlands, the Amazonian region (including Colombia and northwestern Brazil), and central-eastern Brazil (Figure 3a). Working in unexplored areas frequently provides new information on a species in the form of expansion of known distribution ranges and new records of unidentified specimens (Soberón and Peterson 2005; Mota-Vargas and Rojas-Soto 2012; Tôrres et al. 2012; Ortega-Andrade et al. 2013; Rheingantz et al. 2014). Thus, our results aid in identifying unexplored areas where future survey efforts should be focused in order to accelerate the discovery of new populations of water opossum.

Implications for $C$. minimus' conservation. Our results showed areas absent from the IUCN's distribution map, indicating that this needs to be updated. Thus, we proposed a new tentative extent of the water opossum distribution (Figure 3b) which integrated the information obtained in the SDMs, the IUCN historical range, and the newly reported localities. This proposal includes new distribution areas for Mexico, Venezuela, Suriname, Guyana, Ecuador, Peru, Bolivia, and Argentina-Brazil; and at the same time reduces or eliminates areas in northern Brazil and the savanna in Colombia and Venezuela.

Clearly, the limited knowledge about the habitat requirements, distribution range, and information obtained directly from field activities, could explain why the water opossum is currently listed as Least Concern. At the continental level, there are mammals which have been reassigned because threat categories have been based more on anecdotal crite- 
ria than on field surveys and population assessments (e. g., Rheingantz and Trinca 2015). Apart from the problems associated with the lack of data for its categorization (Cuarón et al. 2008), our results in combination with the time elapsed since the first assignment justifies the need for a reassessment of the category, such as was done for L. longicaudis, whose threat category was up-listed from "Least Concern" to "Near Threatened" (Rheingantz and Trinca 2015).

On the other hand, it is important to note that our models showed that there is a disjunction in the distribution of water opossum, observed in the population of southeastern of Brazil (C. m. paraguanensis [Marshall 1978; Damasceno and Astúa 2016]). This disjunct distribution could represent ecological niche differences among subspecies, which could simultaneously affect the performance of our models (see Rojas-Soto et al. 2008; 2009; Mota-Vargas and Rojas-Soto 2016). It is reasonable to suggest that there are climatic and geographic factors acting (or that acted) as geographic barriers that contribute to the isolation of some populations (see Damasceno and Astúa 2016). Similar cases were documented for wide-ranging Didelphidae species: the genus Didelphis, the Black-eared opossums ( $D$. marsupialis; Cerqueira 1985) and White-eared opossums (D. albiventris; Cerqueira and Lemos 2000), and the Lutrine Opossum, Lutreolina crassicaudata (Martínez-Lanfranco et al. 2014). From this perspective, our study suggests that the current taxonomic status of these populations needs to be adequately assessed using tools that could reveal their distinctiveness (Damasceno and Astúa 2016). Independently of the current taxonomic classification, a possible loss of one of these disjunct groups would be irreversible.

Although we only examined the environmental distribution of $C$. minimus, our results forecast a rapid decline in the potential distribution, principally attributed to a decrease in occupancy in areas affected by habitat loss and fragmentation (e. g. Prieto-Torres et al. 2011; Ardente et al. 2013; IUCN 2015; Palmeirim et al. 2014; Fernandez et al. 2015). Modifications to the physicochemical characteristics (e. g., water conditions) of the habitat due to the aforementioned processes can considerably affect water opossum populations and reduce local diversity, as found for other aquatic mammals (e.g., Bowyer et al. 1995; Rheingantz et al. 2014). Thus, considering physicochemical water conditions, the habitat structures to persist, and the habitat requirements to establish a viable population, will be crucial for the conservation of $C$. minimus and the preservation of river ecosystems as a whole.

\section{Acknowledgements}

We would like to acknowledge the contributions of the following organizations and individuals. Financial and logistical support was provided by Consejo de Desarrollo Científico, Humanístico y Tecnológico of Universidad del Zulia (CONDES) by the project CONDES CC-0247-13 (DAPT). Authors extend their gratitude to Consejo Nacional de Ciencia y Tecnología (CONACyT, Mexico) for their post- graduate scholarships (297538 [DAP-T] and 395473 [GPB]). Museums that kindly providing data include: Estación Biológica Rancho Grande (EBRG) and Museo de Historia Natural La Salle (MHNLS) in Venezuela; Grupo de Mastozoología de la Universidad de Antioquia (GMUA) and Colección de Mamíferos "Alberto Cadena García" at Instituto de Ciencias Naturales (ICN), in Colombia; Museo Ecuatoriano de Ciencias Naturales (MECN) and Museo de Zoología de la Pontificia Universidad Católica del Ecuador (QCAZ-PUCE), in Ecuador; the Museo de Historia Natural de la Universidad San Agustín de Arequipa (MUSA), Peru; and the Museo de Historia Natural de Bolivia (MHNB), Bolivia. This manuscript was improved by comments from S. Solari, M. Delgado, F. J. García, and two anonymous reviewers. D. Spaan kindly reviewed the translation.

\section{References}

Acosta, L. S., AND F. H. Azurduy. 2009. Nuevos Registros y apuntes sobre la carachupa de agua Chironectes minimus, en Los Valles Cruceños (Bolivia). Kempffiana 5:83-89.

Anderson, R. P., AND A. RaZA. 2010. The effect of the extent of the study region on GIS models of species geographic distributions and estimates of niche evolution: preliminary tests with montane rodents (genus Nephelomys) in Venezuela. Journal of Biogeography 37:1378-1393.

Ardente, N., D. Gettinger, R. Fonseca, H. de Godoy Bergallo, H., and F. Martins-Hatano. 2013. Mammalia, Didelphimorphia, Didelphidae, Glironia venusta Thomas, 1912 and Chironectes minimus (Zimmermann, 1780): Distribution extension for eastern Amazonia. Check List 9:1104-1007.

Barve, N., V. Barve, A. Jiménez-Valverde, A. Lira-Noriega, S. P. Maher, A. T. Peterson, J. Soberón, AND F. VILlalobos. 2011. The crucial role of the accessible area in ecological niche modeling and species distribution modeling. Ecological Modelling 222:1810-1819. BOWYER, R. T., J. W. TESTA, AND J. B. FARO. 1995. Habitat selection and home ranges of river otters in a marine environment: effects of the Exxon Valdez oil spill. Journal of Mammalogy 76:1-11.

Brandão, M. V., G. S. Terra Garbino, L. Perez Godoy, L. Alves da Silva, AND W. PASCOAL. 2014. New records of Chironectes minimus (Zimmermann, 1780) (Didelphimorphia, Didelphidae) from central Brazil, with comments on its distribution pattern. Mammalia 79:363-368.

Bressiani, V. B., AND M. E. Gralpel. 2008. Comparação de métodos para captura da cuíca-d'água, Chironectes minimus (Zimmermann, 1780) (Mammalia, Didelphidae) no sul do Brasil. Mastozoología Neotropical 15:33-39.

Brown, J. H., G. C. Stevens, And D. M. Kaufman. 1996. The geographic range: size, shape, boundaries, and internal structure. Annual Review of Ecology and Systematics 27:597-623.

Caumer, V. D.; B. Muys, R. Revermann, and A. Trabucco. 2014. Potential, realised, future distribution and environmental suitability for Pterocarpus angolensis DC in southern Africa. Forest Ecology and Management 315:211-226.

Cerqueira, R. 1985. The distribution of Didelphis in South America (Polyprotodontia, Didelphidae). Journal of Biogeography 12:135-145.

Cerqueira, R., AND B. Lemos. 2000. Morphometric differentiation between Neotropical black-eared opossums, Didelphis 
marsupialis and D. aurita (Didelphimorphia, Didelphidae). Mammalia 64:319-327.

Cianfrani, C., G. Le Lay, L. Maiorano, H. F. Satizábal, A. Loy, and A. GUISAN. 2011. Adapting global conservation strategies to climate change at the European scale: The otter as a flagship species. Biological Conservation 144:2068-2080.

Cuarón, A. D., L. Emmons, K. Helgen, F. Reid, D. Lew, B. Patterson, C. Delgado, AND S. Solari. 2008. Chironectes minimus. The IUCN Red List of Threatened Species. http://dx.doi.org/10.2305/IUCN. UK.2008. RLTS.T4671A11076156.en. Accessed 16.06.2016.

Damasceno, E. M., and D. AstúA. 2016. Geographic variation in cranial morphology of the Water Opossum Chironectes minimus (Didelphimorphia, Didelphidae). Mammalian Biology 81:380-392.

DeMatteo, K. E., and B. A. Loiselle. 2008. New data on the status and distribution of the bush dog (Speothos venaticus): Evaluating its quality of protection and directing research efforts. Biological Conservation 141:2494-2505.

Dudley, N., AND J. Parish. 2006. Closing the Gap: Creating ecologically representative protected area systems. Technical Series No. 24. Montreal, QC: Secretariat of the Convention on Biological Diversity, Montreal. U.S. A.

Elith, J., C. H. Graham, R. P. Anderson, M. Dudík, S. Ferrier, A. Guisan, R. J. Hijmans, F. Huettmann, J. R. Leathwick, A. Lehmann, J. LI, L. G. Lohmann, B. A. Loiselle, G. Manion, C. Moritz, M. Nakamura, Y. Nakazawa, J. M. Overton, A. T. Peterson, S. J. Phillips, K. S. Richardoson, R. Scachettı Pereira, R. E. Schapire, J. Soberón, S. Williams, M. S. WisZ, And N. E.Zimmermann. 2006. Novel methods improve prediction of species' distributions from occurrence data. Ecography 29:129-151.

Elith, J., S. J. Phillips, T. Hastie, M. Dudík, Y. E. Chee, and C. J. Yates. 2011. A statistical explanation of MaxEnt for ecologists. Diversity and Distributions 17:43-57.

ESRI (Environmental Systems Research Institute). 2011. ArcGIS Desktop: Release 10, Environmental Systems Research Institute. Redlands, U. S. A.

Fernandez, F. A. S., M. Galliez, M. D. S. Leite, T. L. Queiroz, and A. F. PALmerim. 2015. Natural history of the water opossum Chironectes minimus: a review. Oecologia Australis 19:47-62.

Gallez, M., AND F. A. S Fernandez. 2012. Spatial segregation between the water opossum Chironectes minimus and the water rat Nectomys squamipes: just competition avoidance or a conservation problem as well? Mammalian Biology 77:447-450.

Galliez, M., M. de Souza Leite, T. L. Queiroz, and F. A. S. Fernandez. 2009. Ecology of the Water Opossum Chironectes minimus in Atlantic Forest Streams of Southeastern Brazil. Journal of Mammalogy 90:93-103.

Hannah, L., G. F. Midgley, G. Hughes, and B. Bomhard. 2005. The view from the Cape: extinction risk, protected areas and climate change. BioScience 55:231-42.

Hannah, L, G. Midgley, S. Andelman, M. Araújo, G. Hughes, E. Martinez-Meyer, R. Pearson, and P. Williams. 2007. Protected Area Needs in a Changing Climate. Frontiers in Ecology and the Environment 5:131-138

HANDLEY, C. O., JR. 1976. Mammals of the Smithsonian Venezuelan Project. Brigham Young University Science Bulletin - Biological Series 20:1-91.

Hansen, M. C., P. V. Potapov, R. Moore, M. Hancher, S. A. Turubanova, A. Tyukavina, D. Thau, S. V. Stehman, S. J. Goetz, T. R. Loveland, A.
Kommareddy, A. Egorov, L. ChinI, C. O. Justice, And J. R. G. Townshend. 2013. High-Resolution Global Maps of 21st-Century Forest Cover Change. Science 342:850-53.

Hiumans, R. J., S. E. Cameron, J. L. Parra, P. G. Jones, and A. Jarvis. 2005. Very high resolution interpolated climate surfaces for global land areas. International Journal of Climatology 25:1965-1978.

IUCN. 2001. Categorías y criterios de la Lista Roja de la UICN, Version 3.1. Comisión de Supervivencia de Especies de la UICN. UICN, Gland, Suiza y Cambridge, Reino Unido.

IUCN. 2015. The IUCN Red List of Threatened Species. Version 2015-4. http://www.iucnredlist.org Accessed 14.03.2016.

IUCN, AND UNEP-WCMC. 2012. Protected Planet - The latest initiative harnessing the World Database on Protected Areas. http://www.protectedplanet.net/ Accessed 09.02.2016.

Kübler, D., P. HILdebrandt, S. Günter, B. Stimm, M. Weber, R. MosandL, J. Muñoz, O. Cabrera, N. Aguirre, J. Zellinger, and B. Silva. 2016. Assessing the importance of topographic variables for the spatial distribution of tree species in a tropical mountain forest. Erdkunde 70:19-47.

LariviéRE, S. 1999. Lontra longicaudis. Mammalian Species 609:1-5.

Laurance, W. F., D. C. Useche, J. Rendeiro, M. Kalka, C. J. Bradshaw, S. P. Sloan, S. G. Laurance, M. Campbell, K. Abernethy, P. Alvarez, V. Arroyo-Rodriguez, P. Ashton, J. Benitez-Malvido, A. Blom, K. S. Bobo, C. H. Cannon, M. Cao, R. Carroll, C. Chapman, R. Coates, M. Cords, F. Danielsen, B. De Dijn, E. Dinerstein, M. A. Donnelly, D. Edwards, F. Edwards, N. Farwig, P. Fashing,P. Forget, M. Foster, G. Gale, D. HarRIs, R. HarRISON,J. Hart, S. Karpanty, W. J. KRess, J. KRIShnaswamy, W. Logsdon, J. Lovett,W. Magnusson, F. Maisels, A. R. Marshall, D. McClearn, D. Mudappa, M. R. Nielsen, R. Pearson,N. Pitman, J. van der Ploeg, A. Plumptre, J. Poulsen, M. Quesada, H. Rainey,D. Robinson,C. Roetgers, F. Rovero, F. Scatena, C. Schulze, D. Shell, T. Struhsaker, J. Terborgh, D. Thomas, R. Timm, J. N. Urbina-Cardona, K. Vasudevan, S. J. Wright, J. C. Arias-G.,L. Arroyo, M. Ashton, P. Auzel, D. BabaAsa, F. Babweteera,P. Baker, O. Banki, M. Bass, I. Bila-Isia, S. Blake,W. Brockelman, N. Brokaw, C. A. Brühl, S. Bunyavejchewin, J. T. Chao, J. Chave, R. Chellam, C. J. Clark, J. Clavijo, R. Congdon, R. Corlett, H. S. Dattaraja, C. Dave, G. Davies, B. de Mello Beisiegel, R. Paes da Silva, A. Di Fiore, A. Diesmos, R. Dirzo, D. Doran-Sheehy, M. Eaton, L. Emmons, A. Estrada, C. Ewango, L. Fedigan, F. Feer, B. Fruth, J. Giacalone Willis, U. Goodale, S. Goodman, J. C. Guix, P. Guthiga, W. Haber, K. Hamer, I. Herbinger, J. Hill, Z. Huang, I. Fang Sun, K. ICKes, A. Itoh, N. Ivanauskas, B. Jackes, J. Janovec, D. Janzen, M. Jiangming, C. Jin, T. Jones, H. Justiniano, E. Kalko, A. Kasangaki, T. KilleEn, H. King, E. Klop, C. KNott, I. Koné, E. Kudavidanage, J. L. da Silva Ribeiro, J. Lattke, R. Laval, R. Lawton, M. Leal, M. Leighton, M. Lentino, C. Leonel, J. Lindsell, L. Ling-Ling, K. E. LinsenmaiR, E. Losos, A. Lugo, J. Lwanga, A. L. Mack, M. Martins, W. S. McGraw, R. McNab, L. MontaG, J. Myers Thompson, J. Nabe-Nielsen, M. Nakagawa, S. Nepal, M. Norconk, V. Novotny, S. O'Donnell, M. Opiang, P. Ouboter, K. Parker, N. Parthasarathy, K. Pisciotta, D. Pramiradilaga, C. Pringle, S. Rajathural, U. Reichard, G. Reinartz, K. Renton, G. Reynolds, V. Reynolds, E. Riley, M. O. Rödel, J. Rothman, P. Round, S. Sakal, T. Sanalotti, T. Savini, G. Schaab, J. Seidensticker, A. Siaka, M. R. Silman, T. B. Smith, S. S. de Almeida, N. Sodh, C. Stanford, K. Stewart, E. Stokes, K. E. Stoner, R. Sukumar, M. Surbeck, M. Tobler, T. Tscharntke, A. Turkalo, G. Umapathy, M. van Weerd, J. Vega Rivera, M. Venkataraman, L. Venn, C. Verea, C. Volkmer, M. Waltert, Benjamin Wang, D. Watts, W. Weber, P. West, D. 
Whitacre, K. Whitney,D. Wilkie, S. Williams, D. D. Wright, P. Wright, L. Xiankal, P. Yonzon, and F. Zamzanl. 2012. Averting biodiversity collapse in tropical forest protected areas. Nature 489:290-4.

Lees, A. C., and C. A. Peres. 2006. Rapid avifaunal collapse along the Amazonian deforestation frontier. Biological Conservation 133:198-211.

Lessmann, J., J. Muñoz, and E. Bonaccorso. 2014. Maximizing species conservation in continental Ecuador: a case of systematic conservation planning for biodiverse regions. Ecology and Evolution 2014:1-13.

Liu, C., M. White, M., ANd G. Newell. 2013. Selecting thresholds for the prediction of species occurrence with presence-only data. Journal of Biogeography 40:778-789.

Lobo, J. M., A. Jiménez-Valverde, and R. Real. 2008. AUC: a misleading measure of the performance of predictive distribution models. Global Ecology and Biogeography 17:145-151.

Mares, M. A., K. A. Ernest, and D. D. Gettinger. 1986. Small mammal community structure and composition in the Cerrado Province of central Brazil. Journal of Tropical Ecology 2:289-300.

Marshall, L. G. 1978. Chironectes minimus. Mammalian Species 109:1-6.

Martínez-Lanfranco, J. A., D. Flores, J. P. Jayat, and G. D’Elía. 2014. A new species of Lutrine opossum, genus Lutreolina Thomas (Didelphidae), from the South American Yungas. Journal of Mammalogy 95:225-240.

Mondolfi, E., And G. Medina. 1957. Contribución al conocimiento del "Perrito de agua" (Chironectes minimus Zimmermann). Memoria de la Sociedad de Ciencias Naturales La Salle 48:141-155.

Morrone, J. J. 2014. Biogeographical regionalization of the Neotropical region. Zootaxa 3782:1-110.

Mota-Vargas, C., and O. R. Rojas-Soto. 2012. The importance of defining the geographic distribution of species for conservation: The case of the Bearded Wood-Partridge. Journal for Nature Conservation 20:10-17.

Mota-Vargas, C., and O. R. Rojas-Soto. 2016. Taxonomy and ecological niche modeling: Implications for the conservation of wood partridges (genus Dendrortyx). Journal for Nature Conservation 29:1-13.

Mota-Vargas, C., O. R. Rojas-Soto, C. Lara, and C. Castillo-Guevara. 2013. Geographic and ecological analysis of the Bearded Wood Partridge Dendrortyx barbatus: some insights on its conservation status. Bird Conservation International 23:371385.

Nogueira, J. C., A. C. S. Caster., E. V. C. Câmara, and B. G. O. Câmara. 2004. Morphology of the male genitalia system of Chironectes minimus and comparisons to other didelphid marsupials. Journal of Mammalogy 85:834-841.

NoWAK, R. M. 1999. Walker's mammals of the world. Johns Hopkins University Press. Baltimore, U. S. A.

Numata, I., And M. A. Cochrane. 2012. Forest Fragmentation and Its Potential Implications in the Brazilian Amazon between 2001 and 2010. Open Journal of Forestry 2:265-271.

Oliveira, T. G., R. G. Gerude, AND J. S. Silva Junior. 2007. Unexpected mammalian records in the state of Maranhão: Ocorrências inusitadas de mamíferos no estado do Maranhão. Boletim do Museu Paraense Emílio Goeldi. Ciências Naturais 2:23-32.
Olson, D. M., E. Dinerstein, E. D. Wikramanayake, N. D. Burgess, G. V. Powell, E. C. Underwood, J. A. D'amico, I. itoua, H. E. Strand, J. C. Morriosn, C. J. LOUCKS, T. F. AlLnUtT, T. H. RICKETTS, Y. KuRA, J. F. LAMOREUX, W. W. Wettengel, P. Hedao, and K. R. Kassem. 2001. Terrestrial Ecoregions of the World: A New Map of Life on Earth: A new global map of terrestrial ecoregions provides an innovative tool for conserving biodiversity. BioScience 51:933-938.

Ortega-Andrade, H. M., O. Rojas-Soto, and C. Paucar. 2013. Novel Data on the Ecology of Cochranella mache (Anura: Centrolenidae) and the Importance of Protected Areas for This Critically Endangered Glassfrog in the Neotropics. PLoS ONE 8:e81837.

Ortega-Andrade, H. M., D. Prieto-Torres, I. Gómez-Lora, I., And D. LIzCANO. 2015. Ecological and Geographical Analysis of the Distribution of the Mountain Tapir (Tapirus pinchaque) in Ecuador: Importance of Protected Areas in Future Scenarios of Global Warming. PLoS ONE 10:e0121137.

Palmeirim, A. F., M. de Souza Leite, M. Santos-Reis, and F. A. S. Fernandez. 2014. Habitat selection for resting sites by the water opossum (Chironectes minimus) in the Brazilian Atlantic Forest. Studies on Neotropical Fauna and Environment 49:231-238.

Pearson, R. G., W. Thuiller, M. B. Araújo, E. Martinez-Meyer, L. Brotons, C. McClean, L. Miles, P. Segurado, T. P. Dawson, and D. C. LeES. 2006. Model-based uncertainty in species range prediction. Journal of Biogeography 33:1704-1711.

Peterson, A.T. 2001. Predicting species'geographic distributions based on ecological niche modeling. Condor 103:599-605.

Peterson, A. T., A. G. Navarro-Sigüenza and A. Gordillo. 2016. Assumption- versus data-based approaches to summarizing species' ranges. Conservation Biology.

Peterson, A. T., J. Soberón, R. G. Pearson, R. P. Anderson, E. MartínezMeyer, M. Nakamura \& M. B. Araújo. 2011. Ecological Niches and Geographic Distribution. Press PU, editor. New Jersey, U. S. A.

Peterson, A. T., M. Papeş And J. Soberón. 2008. Rethinking receiver operating characteristic analysis applications in ecological niche modeling. Ecological Modelling 213:63-72.

Phillips, S. J., R. P. Anderson, And R. E. Schapire. 2006. Maximum entropy modeling of species geographic distributions. Ecological Modelling 190:231-259.

PHILLIPS, S. J., AND M. DUBIK. 2008. Modeling of species distributions with Maxent: new extensions and a comprehensive evaluation. Ecography 31:161-175.

Prieto-Torres, D., A. Belandria-Abad, and U. Gómez. 2008. Avistamiento de Chironectes minimus en la Sierra de Perijá, Venezuela. Boletín del Centro de Investigaciones Biológicas 42:567-571.

Prieto-Torres, D., A. Belandria-Abad, U. Gómez, and R. Calchi. 2011. Lista preliminar de mamíferos no voladores en tres localidades de la vertiente suroriental de la Sierra de Perijá, estado ZuliaVenezuela. Boletín del Centro de Investigaciones Biológicas 45:21-34.

Prieto-Torres, D. A., A. G. Navarro-Sigüenza, D. Santiago-Alarcon, AND O. R. Rojas-Soto. 2016. Response of the endangered tropical dry forests to climate change and the role of Mexican Protected Areas for their conservation. Global Change Biology 22:364-379.

R-Core-TeAm. 2012. R: A language and environment for statistical computing [Computer software]. Vienna, Austria: R 
Foundation for Statistical Computing. http://www.R-project. org.

Rheingantz, M. L. AND C. S. TRINCA. 2015. Lontra longicaudis. The IUCN Red List of Threatened Species 2015: e.T12304A21937379. http://dx.doi.org/10.2305/IUCN. UK.2015-2.RLTS.T12304A21937379.en. Downloaded on 16 December 2016.

Rheingantz, M. L., J. F. Saraiva de Menezes, and B. Thoisy. 2014. Defining Neotropical otter Lontra longicaudis distribution, conservation priorities, and ecological frontiers. Tropical Conservation Science 7:214-229.

Ribeiro, M. C., J. P. Metzger, A. Martensen, F. J. Ponzoni, and M. M. HiRotA. 2009. The Brazilian Atlantic Forest: How much is left, and how is the remaining forest distributed? Implications for conservation. Biological Conservation 142:1141-1153.

Rodda, G. H., C. S. Jarnevich, And R. N. Reed. 2011. Challenges in Identifying Sites Climatically Matched to the Native Ranges of Animal Invaders. PLoS ONE 6:e14670.

Rojas-Soto, O. R., E. Martínez-Meyer, A. Navarro-Sigüenza, A. Oliveras de Ita, H. Gómez de Silva, and A. T. Peterson. 2008. Modeling distributions of disjunct populations of the Sierra Madre sparrow. Journal of Field Ornithology 79:245-253.

Rojas-Soto, O. R., A. G. Navarro-Sigüenza, and A. Espinosa De Los Monteros. 2009. Systematics and bird conservation policies: the importance of species limits. Bird Conservation International 20:176-185.

Royle, J. A., R. B. Chandler, C. Yackulic, and J. D. Nichols. 2012. Likelihood analysis of species occurrence probability from presence-only data for modelling species distributions. Methods in Ecology and Evolution 3:545-554.

Shukla, J., C. Nobre, And P. Sellers. 1990. Amazon deforestation and climate change. Science, 247:1322-125.

Soberón, J., And A. T. Peterson. 2005. Interpretation of models of fundamental ecological niches and species' distributional areas. Biodiversity Informatics 2:1-10.

Stein, B. R., And J. L. Patton. 2007. Genus Chironectes Illiger, 1811. Pp. 14-17, in Mammals of South America: Vol. 1. Marsupials, Xenarthrans, Shrews and Bats (Gardner, A. L, ed.). University of Chicago Press. Chicago, U. S. A.

Stohlgren, T. J., C. S. Jarnevich, W. E. Esaias, And J. T. Morisette. 2011. Bounding species distribution models. Current Zoology 57:642-647.

Tôrres, N. M., P. De Marco, T. Santos, L. Silveira, A. T. de Almeida JÁcomo, AND J. A. F. Dinız-Filho. 2012. Can species distribution modelling provide estimates of population densities? A case study with jaguars in the Neotropics. Diversity and Distributions 18:615-627.

USGS. 2001. HYDRO1k Elevation Derivate Database [Dataset]. Sioux Falls, SD: U.S. Geological Survey Earth Resources Observation and Science (EROS) Center. https://lta.cr.usgs. gov/HYDRO1K Accessed 16.06.2016.

Voss, R. S., AND S. A. JANSA. 2009. Phylogenetic relationships and classification of didelphid marsupials, an extant radiation of New World metatherian mammals. Bulletin of the American Museum of Natural History 322:1-177.

ZimmermanN, E. 1780. Geographische Geschichte der Menschen, und der algemein verbreiteten Vierfüssigen Thiere. Zweiter Band. Leipzig: Wenganschen Buchhandlung 2:6.
Associated editor: Sergio Solari

Submitted: January 8, 2017; Reviewed: May 1, 2017;

Accepted:May 16, 2017; Published on line:May 25, 2017. 


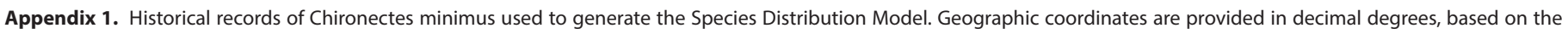

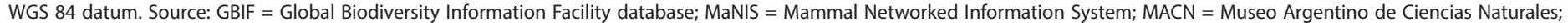

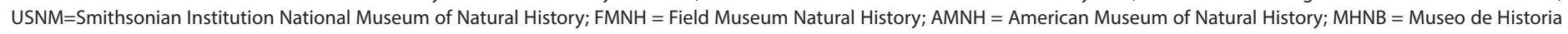

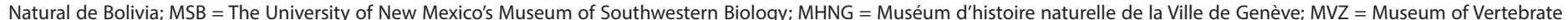

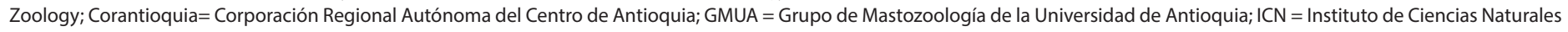

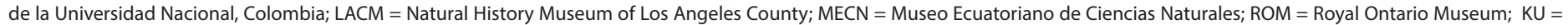

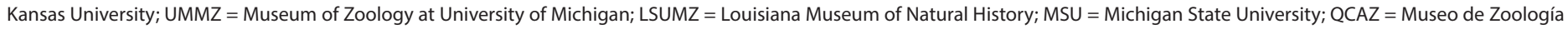

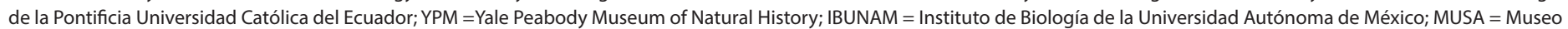

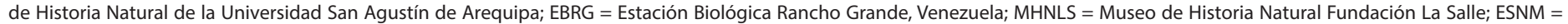
Earth Science Museum.

\begin{tabular}{|c|c|c|c|c|c|c|}
\hline $\mathbf{N}^{\circ}$ & Country & State/Province & Longitud & Latitud & Elevation (m) & Source \\
\hline 1 & Argentina & Misiones & -54.2540 & -25.9400 & 223 & MACN 13547, 13548 \\
\hline 2 & Argentina & Misiones & -53.8957 & -25.9817 & 545 & MACN 13053 \\
\hline 3 & Argentina & Misiones & -54.2707 & -26.2817 & 298 & GBIF/MaNIS \\
\hline 4 & Argentina & Misiones & -54.8540 & -26.8233 & 203 & MACN 13175, 13210 \\
\hline 5 & Argentina & Misiones & -54.6874 & -27.0233 & 538 & MACN 24435 \\
\hline 6 & Argentina & Misiones & -54.8707 & -27.1400 & 419 & GBIF/MaNIS \\
\hline 7 & Argentina & Misiones & -54.6540 & -27.2650 & 352 & GBIF/MaNIS \\
\hline 8 & Argentina & Misiones & -55.9540 & -27.4483 & 130 & GBIF/MaNIS \\
\hline 9 & Argentina & Misiones & -55.1374 & -27.8733 & 102 & GBIF/MaNIS \\
\hline 10 & Argentina & Misiones & -54.7124 & -26.4650 & 140 & GBIF/MaNIS \\
\hline 11 & Belize & Stann Creek & -88.5289 & 16.7765 & 150 & USNM 583002 \\
\hline 12 & Belize & Toledo & -88.5039 & 17.2515 & 42 & FMNH 151051 \\
\hline 13 & Bolivia & La Paz & -67.3123 & -15.4400 & 1,000 & AMNH 264571, 264572, 264573 \\
\hline 14 & Bolivia & La Paz & -67.5207 & -15.7317 & 985 & $\begin{array}{l}\text { MHNB 2294; MSB 68329, 68330, 235667, 235796, 235827, } \\
235892,235893\end{array}$ \\
\hline 15 & Bolivia & La Paz & -67.5123 & -15.7317 & 1,161 & MSB 141635 \\
\hline 16 & Bolivia & La Paz & -68.8873 & -15.1317 & 2,995 & AMNH 34121 \\
\hline 17 & Bolivia & Santa Cruz & -64.2123 & -17.9817 & 1,831 & Literature (Acosta \& Azurday 2009) \\
\hline 18 & Bolivia & Santa Cruz & -63.7623 & -18.1900 & 1,451 & Literature (Acosta \& Azurday 2009) \\
\hline 19 & Bolivia & Santa Cruz & -63.7290 & -18.4817 & 1,285 & Literature (Acosta \& Azurday 2009) \\
\hline 20 & Bolivia & Santa Cruz & -63.8123 & -18.5234 & 2,119 & Literature (Acosta \& Azurday 2009) \\
\hline 21 & Bolivia & Santa Cruz & -63.9790 & -18.6567 & 1,760 & Literature (Acosta \& Azurday 2009) \\
\hline 22 & Brazil & Bahia & -41.2874 & -11.2817 & 904 & MHNG 510.062, 713.027 \\
\hline 23 & Brazil & Goiás & -47.5167 & -14.1167 & 1,149 & Literature (Brandão et al. 2014) \\
\hline 24 & Brazil & Goiás & -50.9333 & -18.7500 & 572 & Literature (Brandão et al. 2014) \\
\hline 25 & Brazil & Maranhao & -46.0207 & -2.6651 & 98 & Literature (Oliveira et al. 2007) \\
\hline 26 & Brazil & Maranhao & -46.1541 & -3.7484 & 79 & Literature (Oliveira et al. 2007) \\
\hline 27 & Brazil & Maranhao & -46.5041 & -4.5984 & 126 & Literature (Oliveira et al. 2007) \\
\hline 28 & Brazil & Mato Grosso & -51.1250 & -10.0194 & 309 & Literature (Brandão et al. 2014) \\
\hline 29 & Brazil & Mato Grosso & -52.4736 & -14.7925 & 367 & Literature (Brandão et al. 2014) \\
\hline 30 & Brazil & Mato Grosso & -57.2167 & -15.6500 & 447 & Literature (Brandão et al. 2014) \\
\hline 31 & Brazil & Minas Gerais & -47.3041 & -16.0484 & 883 & MVZ 197759 \\
\hline 32 & Brazil & Para & -49.5041 & -2.2484 & 1 & FMNH 48933, 50908 \\
\hline 33 & Brazil & Sao Paulo & -47.6707 & -24.2817 & 152 & FMNH 94292 \\
\hline 34 & Brazil & Tocantins & -48.1283 & -10.2972 & 426 & Literature (Brandão et al. 2014) \\
\hline 35 & Colombia & Antioquia & -75.2040 & 7.9932 & 71 & Corantioquia \\
\hline 36 & Colombia & Antioquia & -75.3540 & 7.5765 & 130 & Corantioquia \\
\hline 37 & Colombia & Antioquia & -74.8706 & 7.5015 & 87 & Corantioquia \\
\hline 38 & Colombia & Antioquia & -75.7706 & 7.1765 & 1,294 & Corantioquia \\
\hline 39 & Colombia & Antioquia & -75.1540 & 7.0682 & 1,544 & Corantioquia \\
\hline 40 & Colombia & Antioquia & -74.5040 & 6.9182 & 386 & GMUA \\
\hline 41 & Colombia & Antioquia & -75.0706 & 6.9099 & 1,667 & Corantioquia \\
\hline 42 & Colombia & Antioquia & -76.2540 & 6.8099 & 1,443 & GMUA \\
\hline
\end{tabular}




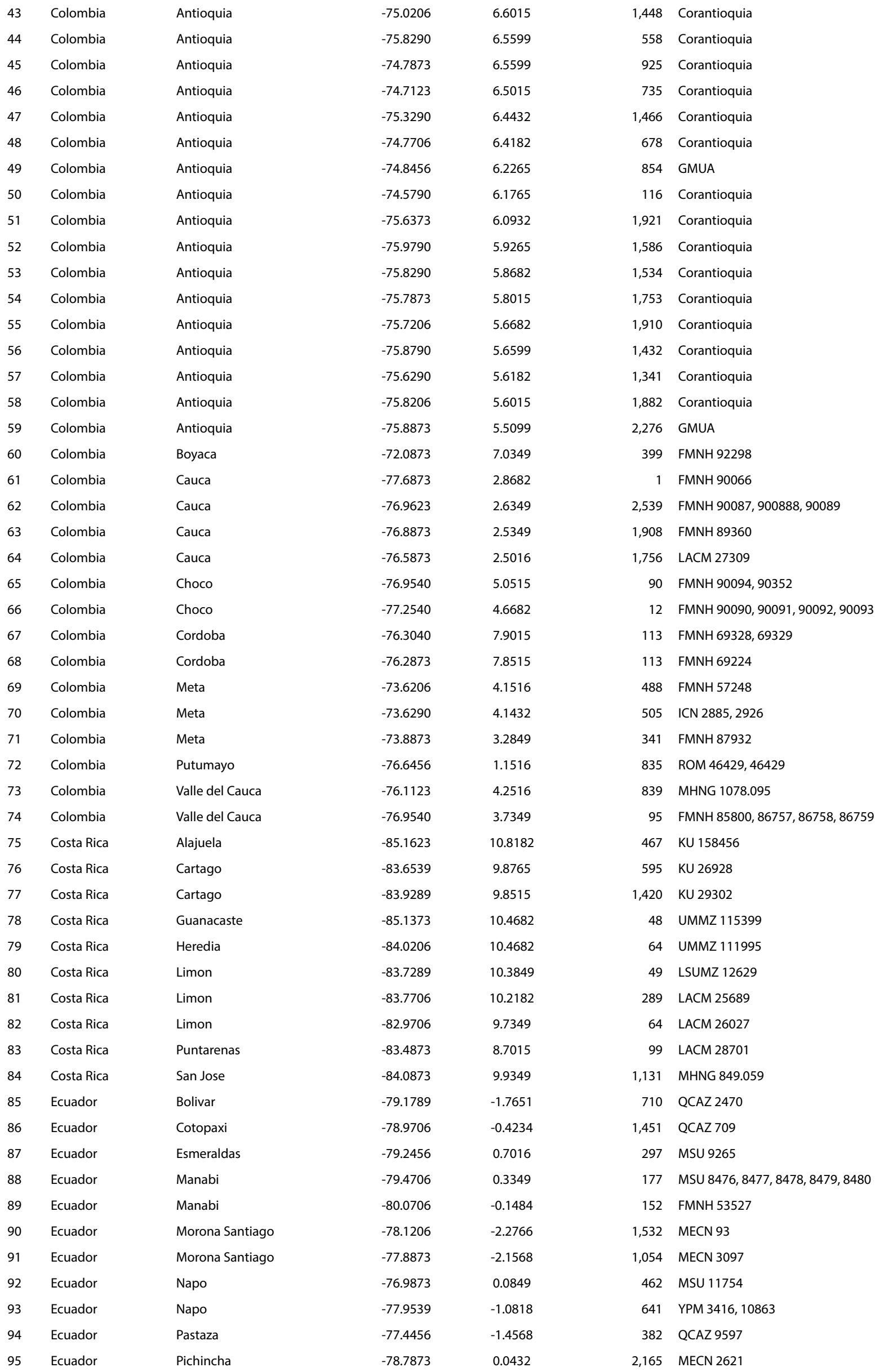




\begin{tabular}{|c|c|c|c|c|c|c|}
\hline 96 & Ecuador & Pichincha & -78.8039 & -0.0318 & 1,482 & UMMZ 155684, 155685, 155686 \\
\hline 97 & Ecuador & $\begin{array}{l}\text { Santo Domingo de los } \\
\text { Tsáchilas }\end{array}$ & -78.8206 & -0.2318 & 1,938 & QCAZ 2585 \\
\hline 98 & Ecuador & $\begin{array}{l}\text { Santo Domingo de los } \\
\text { Tsáchilas }\end{array}$ & -78.7956 & -0.2318 & 1,894 & QCAZ 2068 \\
\hline 99 & Ecuador & Sucumbios & -76.4373 & -0.2568 & 268 & MHNG 1706.007 \\
\hline 100 & El Salvador & La Libertad & -89.4706 & 13.7682 & 455 & MVZ 43258, 130323, 130324, 130325, 130326, 1303237 \\
\hline 101 & Guatemala & Izabal & -88.6622 & 15.6765 & 278 & KU 140279, 140280 \\
\hline 102 & Guyana & Barima-Waini & -59.3874 & 7.5182 & 50 & ROM 98855 \\
\hline 103 & Mexico & Chiapas & -93.0789 & 17.5265 & 98 & KU 102259 \\
\hline 104 & Mexico & Chiapas & -93.0872 & 17.4432 & 156 & IBUNAM 24623 \\
\hline 105 & Mexico & Chiapas & -91.8122 & 16.4765 & 2,188 & LACM 18911 \\
\hline 106 & Mexico & Chiapas & -90.8956 & 16.1515 & 154 & IBUNAM 21005 \\
\hline 107 & Mexico & Chiapas & -90.9206 & 16.1348 & 174 & IBUNAM 22980 \\
\hline 108 & Mexico & Chiapas & -90.9289 & 16.1265 & 185 & IBUNAM 22189 \\
\hline 109 & Mexico & Tabasco & -92.9039 & 17.7765 & 24 & LSUMZ 8102, 8665, 8666; UMMZ 119456 \\
\hline 110 & Mexico & Tabasco & -92.9539 & 17.5848 & 49 & LSUMZ 8098, 8099, 8100, 8101, 8103 \\
\hline 111 & Mexico & Tabasco & -92.9706 & 17.5682 & 65 & LSUMZ 8099, 8100, 8101, 8103 \\
\hline 112 & Mexico & Tabasco & -92.9289 & 17.5682 & 64 & IBUNAM 26122 \\
\hline 113 & Mexico & Tabasco & -92.8039 & 17.5515 & 49 & IBUNAM 6960, 6961, 6962 \\
\hline 114 & Nicaragua & Boaco & -85.5206 & 12.6099 & 354 & KU $110653,110654,110655,114474$ \\
\hline 115 & Nicaragua & Boaco & -85.8372 & 12.4099 & 147 & KU $114475,114476,114477,114478,114479$ \\
\hline 116 & Nicaragua & Boaco & -85.6539 & 12.3432 & 263 & $\begin{array}{l}\text { KU } 114480,114481,114482,114483,114484,114485 \text {, } \\
114486,114487,114488,114489,114490\end{array}$ \\
\hline 117 & Nicaragua & Matagalpa & -85.7872 & 12.9182 & 1,004 & KU 70194 \\
\hline 118 & Nicaragua & Nueva Segovia & -86.1122 & 13.9265 & 652 & KU 110651,110652 \\
\hline 119 & Nicaragua & Zelaya & -84.3123 & 12.1682 & 36 & KU 114491 \\
\hline 120 & Nicaragua & Zelaya & -84.4623 & 12.1099 & 99 & KU 110656 \\
\hline 121 & Panama & Chiriqui & -82.7456 & 8.8599 & 1,226 & USNM 516614 \\
\hline 122 & Panama & Colón & -79.7039 & 9.1182 & 51 & MSU 33109 \\
\hline 123 & Panama & Darien & -77.2873 & 8.1849 & 1,278 & UMMZ 165354 \\
\hline 124 & Paraguay & Cordilleras & -57.0540 & -25.5483 & 307 & MVZ 144314 \\
\hline 125 & Paraguay & Itapua & -56.3874 & -27.1150 & 88 & UMMZ 126289 \\
\hline 126 & Paraguay & Paraguari & -57.3207 & -25.8067 & 74 & UMMZ 124681 \\
\hline 127 & Paraguay & Paraguari & -57.0540 & -26.0150 & 108 & UMMZ 134022, 134023, 134024, 134025, 134559, 134560 \\
\hline 128 & Paraguay & Paraguari & -56.8374 & -26.0983 & 92 & MHNG 1624 \\
\hline 129 & Peru & Amazonas & -78.1289 & -4.3151 & 724 & MVZ 153307 \\
\hline 130 & Peru & Cuzco & -73.4956 & -11.3901 & 931 & MUSA 8620,8621 \\
\hline 131 & Peru & Cuzco & -70.5873 & -13.2484 & 493 & FMNH 75092 \\
\hline 132 & Peru & Cuzco & -70.6373 & -13.2650 & 569 & FMNH 75090, 75091 \\
\hline 133 & Peru & Cuzco & -70.7206 & -13.3984 & 2,846 & FMNH 68335,75093 \\
\hline 134 & Peru & Huanuco & -75.9206 & -9.5234 & 979 & MUSA 13444, 13457 \\
\hline 135 & Peru & Loreto & -73.0873 & -3.8317 & 106 & FMNH 106721 \\
\hline 136 & Peru & Loreto & -71.2206 & -10.1317 & 265 & LSUMZ 9263, 10003, 10004, 10005, 14842, 14843 \\
\hline 137 & Peru & Madre de Dios & -71.2206 & -12.6650 & 769 & FMNH 122188 \\
\hline 138 & Peru & Madre de Dios & -71.3873 & -12.8484 & 1,002 & MVZ 166507 \\
\hline 139 & Peru & Pasco & -75.5373 & -10.0651 & 784 & FMNH 24791 \\
\hline 140 & Peru & Pasco & -75.2206 & -10.1067 & 299 & MUSA 10222 \\
\hline 141 & Peru & Puno & -69.2540 & -14.1567 & 2,959 & FMNH 79921 \\
\hline 142 & Peru & San Martín & -76.9706 & -6.0484 & 732 & FMNH 19349 \\
\hline 143 & Peru & San Martín & -76.9706 & -6.0567 & 732 & FMNH 19350 \\
\hline 144 & Venezuela & Amazonas & -67.6540 & 5.4015 & 153 & USNM 406972 \\
\hline 145 & Venezuela & Amazonas & -64.9207 & 4.5182 & 1,183 & EBRG 17818 \\
\hline 146 & Venezuela & Amazonas & -65.7873 & 3.7349 & 348 & MHNLS 7584 \\
\hline
\end{tabular}




\begin{tabular}{|c|c|c|c|c|c|c|}
\hline 147 & Venezuela & Aragua & -67.6957 & 10.4849 & 167 & EBRG 1683, 1684, 1685, 1686, 1687, 1688, 2370, 2371, 16959 \\
\hline 148 & Venezuela & Aragua & -67.7707 & 10.4015 & 270 & USNM 517235, 517237 \\
\hline 149 & Venezuela & Aragua & -67.6790 & 10.4015 & 1,167 & EBRG 16899 \\
\hline 150 & Venezuela & Aragua & -67.6873 & 10.3515 & 972 & UMMZ 110966 \\
\hline 151 & Venezuela & Aragua & -67.6290 & 10.3182 & 647 & USNM 517241 \\
\hline 152 & Venezuela & Aragua & -67.6290 & 10.3015 & 611 & EBRG 142 \\
\hline 153 & Venezuela & Aragua & -67.6040 & 10.2765 & 715 & ESNM 517236, 517238, 517239, 517240 \\
\hline 154 & Venezuela & Aragua & -67.2707 & 10.2432 & 612 & MHNLS 580, 581, 582 \\
\hline 155 & Venezuela & Bolivar & -66.6790 & 6.4432 & 852 & EBRG 15944 \\
\hline 156 & Venezuela & Bolivar & -64.8207 & 4.9765 & 923 & MHNLS 875 \\
\hline 157 & Venezuela & Bolivar & -64.1558 & 5.1150 & 378 & MHNLS 12031 \\
\hline 158 & Venezuela & Delta Amacuro & -60.7290 & 8.4432 & 1 & MHNLS 10596, 10807 \\
\hline 159 & Venezuela & Merida & -71.1540 & 8.6265 & 1,780 & EBRG 4125,4126 \\
\hline 160 & Venezuela & Merida & -71.1540 & 8.6182 & 1,780 & USNM 385097 \\
\hline 161 & Venezuela & Miranda & -66.2790 & 10.4265 & 167 & MHNLS 3685, 3686, 3687 \\
\hline 162 & Venezuela & Miranda & -66.4540 & 10.0599 & 550 & MHNLS 1144 \\
\hline 163 & Venezuela & Monagas & -63.5290 & 10.2015 & 1197 & USNM 406985 \\
\hline 164 & Venezuela & Yaracuy & -68.9040 & 10.4182 & 682 & USNM 418562 \\
\hline 165 & Venezuela & Zulia & -72.8456 & 9.8849 & 616 & Literature (Prieto-Torres et al., 2008, 2011) \\
\hline
\end{tabular}

